\title{
Welfare indicators for laying Japanese quails caged at different densities
}

\author{
DANIELA F. SOARES ${ }^{1}$, CARLA C. PIZZOLANTE ${ }^{2}$, KEILA MARIA R. DUARTE ${ }^{3}$, JOSÉ EVANDRO \\ DE MORAES ${ }^{2}$, FÁBIO E.L. BUDIÑO ${ }^{2}$, WEBER V.B. SOARES ${ }^{2}$ and SÉRGIO K. KAKIMOTO ${ }^{4}$ \\ ${ }^{1}$ Programa de Pós-Gradução em Produção Animal Sustentável, Instituto de Zootecnia/IZ/APTA/SAA, Centro \\ de Pesquisa em Zootecnia Diversificada, Rua Heitor Penteado, 56, 13460-000 Nova Odessa, SP, Brazil \\ ${ }^{2}$ Instituto de Zootecnia/IZ/APTA/SAA, Centro de Pesquisa em Zootecnia Diversificada, \\ Rua Heitor Penteado, 56, 13460-000 Nova Odessa, SP, Brazil \\ ${ }^{3}$ Unidade de Pesquisa e Desenvolvimento Tietê/APTA/SAA, Polo Centro Sul, Rodovia \\ SP 127, Km $69+100$ metros, Caixa Postal 18, 18530-000 Tietê, SP, Brazil \\ ${ }^{4}$ Granja Kakimoto, Estrada Seção Cascata, Km 7, 17690-000 Bastos, SP, Brazil
}

Manuscript received on March 29, 2018; accepted for publication on June 18, 2018

\begin{abstract}
In the way to reduce costs in the poultry production, high densities of birds are adopted in the production systems. Such high densities can lead to an inappropriate environment, compromising the welfare and decreasing the animal performance. In this work we aimed to evaluate the effects of different densities on the productive yield, egg quality and immunological aspects of Japanese quails. It was used 816 Japanese quails, during egg production phase, in a random design, with four treatments $\left(121.43 \mathrm{~cm}^{2} / \mathrm{bird} ; 106.25\right.$ $\mathrm{cm}^{2} /$ bird; $94.44 \mathrm{~cm}^{2} /$ bird and $85.00 \mathrm{~cm}^{2} /$ bird) with six repetitions each. Results indicate density did not interfere on egg quality and all treatments can be considered excellent, once the Haugh Unit was 88.03. Therefore, higher densities decline the yield, decreasing the eggs weight $(10.35 \mathrm{~g})$, the laying percentage (88\%), egg mass (9.16 g) and the week average feed consumption (157.35 g). IgY values were higher at smaller cage density, suggesting birds in this condition presented better immunological condition, related to welfare and stress factors, all linked to immunoglobulins IgY.
\end{abstract}

Key words: immunity, IgY, egg quality, Haugh Unit.

\section{INTRODUCTION}

Japanese quails are worldwide known as precocious and high productive animals, giving meat and eggs (Albino and Barreto 2012). To produce Japanese quail, it is economically viable and this marked is growing every year (Pastore et al. 2012). Saka et al. (2018) reported the experience of farms in Nigeria with eggs and quails meat, with surprise

Correspondence to: Keila Maria Roncato Duarte

E-mail: keiladuarte@globo.com success, despite lack of processing market for meat, veterinary support and technology. Even with those problems, quail farm showed to be a lucrative business and a source of protein for families.

In order to reduce costs with cages and equipment, farmers use high density of birds per cage. Such practice is very common and can be seen as aggressive but generally did not interfere in the production system (Leandro et al. 2005). The maximization of the production system has brought some issues about the birds welfare 
(Faitarone et al. 2005), once the area per bird is reduced, as well as the feeding area and the water area, causing increase on the stress and at the end, in the final production, as eggs or meat (Carey et al. 1995), interfering on the feed consumption and its performance (Pavan et al. 2005).

For Molento (2005), welfare can be evaluated by physiological data as the increasing of cardiac frequency, adrenal activity or by immunological response.

Birds are able to transfer antibodies from mother's blood to egg yolk, giving passive immunity to embryo and to neoborn (Klemperer 1893). Total concentration of immunoglobulins $\mathrm{Y}$ can indicate the health condition and nutritional aspect of the birds (Apanius 1998). Sun et al. (2013) reported a significant correlation from IgY level in total serum and $\mathrm{IgY}$ in egg yolk, indicating hens with higher levels of IgY in blood show higher levels in egg yolk and are able to transfer better immunological capabilities to the eggs.

Birds need a defense mechanism to resist to microorganism infections. Therefore, Squires (2003) report in stressing environments it can work as immunosuppresses, in this case, birds became more susceptible to diseases.

To the present, only few studies were done relating cage density of Japanese quails to productive performance, egg quality and immunology, which was the objective of this study.

\section{MATERIALS AND METHODS}

All procedures were carried out according to the international practices for animal use and care, approved by the Committee of Ethics and Animal Experimentation, from the Institute of Zootechny, Nova Odessa, protocol no. 217-15.

The experimental design was done at Institute of Zootechny, Nova Odessa-SP - Brazil, during 2015, with the aim to evaluate the welfare conditions and possible effects on the productive performance and egg quality of Japanese quails at different cage densities.

Experiment was performed for 63 days, with three productive cycles of 21 days each. Light was settled for 16 hours a day. It was used 816 Japanese quails (Coturnix coturnix japonica), with 132 days of age, during laying phase. Cages had the following dimensions: $100 \times 34 \times 16 \mathrm{~cm}$; with four internal partitions of $25 \mathrm{~cm}$ each. Each cage had four drinking nipples, feeder (trough type). Water and food ad libitum. Experimental design randomly, with casualysed blocks, with four treatments and six repetitions. Treatments were: $\mathrm{T} 1=7$ birds/partition, $12.43 \mathrm{~cm}^{2} /$ bird $(28$ birds per parcel); T2 $=8$ birds/partition, $10.25 \mathrm{~cm}^{2} /$ bird (32 birds per parcel); T3 $=9$ birds/partition, 94.44 $\mathrm{cm}^{2} /$ bird (36 birds per parcel) and T4 $=10$ birds/ partition, $85.00 \mathrm{~cm}^{2} /$ bird (40 birds per parcel).

Feed was kept in buckets, in front of the cages and the buckets were filled at the beginning of each week. Leftovers from each week were weighted at the end of each week. Diet was based upon corn and soybean bran (Table I). Chemical composition, nutritional values and ingredients were according to Rostagno et al. (2011).

Productive performance was evaluated weekly by: number of eggs produced, egg production, feed consumption, average weight of eggs, egg mass, feed conversion per egg dozen, feed conversion per egg kilograms produced, mortality and viability. At the end of each cycle, those parameters were analyzed, for egg quality: egg weight, yolk percentage, albumen percentage, shell percentage, egg yolk color, Haugh Unit, shell thickness and yolk indices.

Immunological evaluation of quails was done by purification and quantification immunoglobulins Y. Purifications were performed using the commercial kit "Thermo Scientific Pierce Chicken IgY Purification", which purifies IgY from egg yolk and isolate the $\operatorname{IgY}$ fractions, which can be quantified by spectrophotometer, at $280 \mathrm{~nm}$. 
TABLE I

Diet composition of the experimental feed for Japanese quail during production phase.

\begin{tabular}{lc}
\hline INGREDIENTS & Amount $(\mathbf{K g})$ \\
\hline Corn & 51.30 \\
Soybean bran & 37.00 \\
Calcarius 38\% Ca & 7.00 \\
Vegetal oil & 2.00 \\
Bicalcium Phosphate & 1.30 \\
Mineral vitamins supplement $^{1}$ & 0.60 \\
Salt & 0.40 \\
\hline TOTAL & 100 \\
\hline
\end{tabular}

NUTRITIONAL LEVELS

\begin{tabular}{lc} 
Metabolic energy & $2,838.50(\mathrm{Kcal} / \mathrm{kg})$ \\
Crude Protein & $21.93(\%)$ \\
Ethereal extract & $4.59(\%)$ \\
Calcium & $3.37(\%)$ \\
Total Phosphorus & $0.69(\%)$ \\
Available Phosphorus & $0.47(\%)$ \\
Sodium & $0.18(\%)$ \\
Total Lisine & $1.24(\%)$ \\
Total Metionine & $0.47(\%)$ \\
Met + Cistine & $0.81(\%)$ \\
Total Treonine & $0.84(\%)$ \\
Total Valine & $1.01(\%)$ \\
Xantophile & $9.23(\mathrm{mg})$ \\
\hline
\end{tabular}

${ }^{1}$ Enrichment per kilogram of food: Vit. A - 12,000.00 UI, Vit. $\mathrm{D}_{3}-2,899.99 \mathrm{UI}$, Vit. E $-21.00 \mathrm{UI}$, Vit. $\mathrm{K}_{3}-3.19 \mathrm{mg}$, Vit. $\mathrm{B}_{1}$ $-3.00 \mathrm{mg}$, Vit. $\mathrm{B}_{2}-6.00 \mathrm{mg}$, Vit. $\mathrm{B}_{6}-4.09 \mathrm{mg}$, Vit. $\mathrm{B}_{12}-12.00$ $\mathrm{mcg}$, Niacine $-40.99 \mathrm{mg}$, Pantotenic acid $-30.00 \mathrm{mg}$, Folic acid - $1.00 \mathrm{mg}$, Biotine $-0.10 \mathrm{mg}$, Antioxidant (B.H.T) -0.10 $\mathrm{mg}$, Fitase $-300.00 \mathrm{ftu}$, Endo-1,4-Beta xilanase - $1500.00 \mathrm{u}$. Metionine $-1.36 \mathrm{~g}$, Lisine $-0.55 \mathrm{~g}$, Treonine $-0.34 \mathrm{~g}$, Coline$0.15 \mathrm{~g}$, Betaine $-0.28 \mathrm{~g}, \mathrm{Cu}-10.00 \mathrm{mg}, \mathrm{Fe}-49.99 \mathrm{mg}, \mathrm{I}-$ $1.20 \mathrm{mg}, \mathrm{Mn}-0.08 \mathrm{~g}, \mathrm{Se}-0.28 \mathrm{mg}, \mathrm{Zn}-0.06 \mathrm{~g}$.

Performance and egg quality were submitted to a variance statistical analysis software $\mathrm{R}$ (R Core Team 2015). The data were subjected to analysis of variance and the least square means were compared using Tukey test at $\mathrm{p}<0.05$.

\section{RESULTS AND DISCUSSION}

\section{YIELD PERFORMANCE}

In poultry production system, mainly in Japanese quail system, any type of enhancing ingredient added to the feed, or managing improving can lead to a better quality on eggs production and on meat production (Ghayas et al. 2017, Gitoee et al. 2018, Batkowska et al. 2018). Batkowska et al. (2018) suggest treatments post harvesting eggs can enhance quality, such as the use of propolis as a disinfectant; Gitoee et al. (2018) and Ghayas et al. (2017) suggest addition of chromium and glycerin, respectively to improve egg quality in quail production. Consumption can be influenced by several factors, such as density, heat stress, competition, etc (Garcia et al. 2015, Gitoee et al. 2018).

The results of feed consumption are presented in Table II, in which the values of total feed consumption show that consumption at treatment 4 and 3 were higher. However, for the average weekly ration consumption and the average daily ration consumption per bird, treatment 1 presented higher values when compared to the other treatments. This occurred probably because the area available per animal in the feeder was lower in treatments 2, 3 and 4, that is, there was a greater dispute for food. These data corroborate with the data found by Garcia et al. (2015) who worked with commercial laying hens, and by Lima et al. (2012) who found higher consumption when quails were at lower densities and lower consumption when they were at higher densities.

As a consequence of a lower feed intake, treatment 4 presented lower egg weight, 10.35 $\mathrm{g}$, a posture rate of $88 \%$ and an egg mass of 9.18 $\mathrm{g}$, while in the lower density treatment the egg weight was $10.92 \mathrm{~g}, 100 \%$ posture and egg mass $9.86 \mathrm{~g}$ (Table III). This is because, according to Garcia et al. (2015), birds probably cannot meet their nutritional requirements, with egg production declining. The results obtained are in agreement 
TABLE II

Density effects over the total feed consumption (TFC), average feed consumption per bird (AFC) and average daily bird consumption (ADC).

\begin{tabular}{lccc}
\hline TRAT & TFC $(\mathbf{g})$ & AFC $(g)$ & ADC $(g)$ \\
\hline 1 (7 birds/partition) & $51087.60 \mathrm{a}$ & $182.41 \mathrm{a}$ & $26.06 \mathrm{a}$ \\
2 (8 birds/partition) & $54357.43 \mathrm{~b}$ & $173.78 \mathrm{~b}$ & $24.82 \mathrm{~b}$ \\
3 (9 birds/partition) & $59737.77 \mathrm{c}$ & $166.45 \mathrm{~b}$ & $23.78 \mathrm{~b}$ \\
4 (10 birds/partition) & $61937.95 \mathrm{c}$ & $157.35 \mathrm{c}$ & $22.47 \mathrm{~b}$ \\
\hline average & 5678.02 & 170.00 & 24.28 \\
VC (\%) & 3.04 & 2.86 & 2.86
\end{tabular}

Averages followed by lower case letters in the same column do not differ statistically (Tukey, $5 \%$ ). VC\% means variation coefficient.

TABLE III

Density effects on eggs weight (EW), laying (L) and mortality (MORT).

\begin{tabular}{lccc}
\hline TRAT & EW (g) & L (\%) & MORT (g) \\
\hline 1 (7 birds/partition) & $10.92 \mathrm{a}$ & $100 \mathrm{a}$ & $9.86 \mathrm{a}$ \\
2 (8 birds/partition) & $10.68 \mathrm{a}$ & $99 \mathrm{a}$ & $9.55 \mathrm{ab}$ \\
3 (9 birds/partition) & $10.66 \mathrm{ab}$ & $95 \mathrm{a}$ & $9.13 \mathrm{~b}$ \\
4 (10 birds/partition) & $10.35 \mathrm{~b}$ & $88 \mathrm{~b}$ & $9.18 \mathrm{c}$ \\
\hline average & 10.65 & 95.7 & 9.18 \\
VC (\%) & 1.93 & 4.26 & 4.79 \\
\hline
\end{tabular}

Averages followed by lower case letters in the same column do not differ statistically (Tukey, $5 \%$ ). VC\% means variation coefficient.

with those of Jalal et al. (2006), who evaluated different levels of density of commercial laying hens, concluding that, as the number of birds in the cage increased, feed consumption, egg laying and egg weight decreased while the mortality rate increased.

No significant effects $(\mathrm{p}>0.05)$ were observed for viability $(\%)$, feed conversion per dozen and feed conversion per $\mathrm{kg}$ in none of the evaluated treatments (Table IV). The same occurred in the work of Garcia et al. (2015) analyzing CA / kg for laying hens at different densities. However, these data differ from those found by Lima et al. (2012), which presented better values of CA / DZ and CA / $\mathrm{kg}$ for the lowest housing density.
TABLE IV

Density effect on viability (VIAB), feed conversion per dozen eggs ( FC/DZ) and feed conversion per kilo (FC/Kg).

\begin{tabular}{lccc}
\hline TRAT & VIAB (\%) & FC/DZ & FC/Kg \\
\hline 1 (7 birds/partition) & 100.00 & 0.34 & 2.66 \\
2 (8 birds/partition) & 99.85 & 0.34 & 2.61 \\
3 (9 birds/partition) & 99.60 & 0.33 & 2.61 \\
4 (10 birds/partition) & 99.46 & 0.33 & 2.75 \\
\hline average & 99.72 & 0.34 & 2.66 \\
VC (\%) & 0.35 & 3.29 & 3.77 \\
\hline
\end{tabular}

TABLE V

Densities effect over egg weigh (EW) specific gravity (SG), egg color (EC), shell thickness ( ST) and Haugh Unit (HU).

\begin{tabular}{|c|c|c|c|c|c|}
\hline TRAT & $\begin{array}{c}\text { EW } \\
(\mathrm{g})\end{array}$ & $\begin{array}{c}\mathrm{SG} \\
\left(\mathrm{g} / \mathrm{cm}^{3}\right)\end{array}$ & EC & $\begin{array}{c}\mathrm{ST} \\
(\mathrm{mm})\end{array}$ & HU \\
\hline $\begin{array}{l}1 \text { ( } 7 \text { birds/ } \\
\text { partition) }\end{array}$ & 11.09 & 1.075 & 5.25 & 0.21 & 86.43 \\
\hline $\begin{array}{l}2 \text { ( } 8 \text { birds/ } \\
\text { partition) }\end{array}$ & 11.02 & 1.075 & 5.16 & 0.21 & 89.87 \\
\hline $\begin{array}{l}3 \text { ( } 9 \text { birds/ } \\
\text { partition) }\end{array}$ & 11.06 & 1.074 & 4.91 & 0.21 & 88.60 \\
\hline $\begin{array}{l}4 \text { (10 birds/ } \\
\text { partition) }\end{array}$ & 11.24 & 1.075 & 5.33 & 0.21 & 87.23 \\
\hline average & 11.1 & 1.075 & 5.16 & 0.21 & 88.03 \\
\hline VC (\%) & 3.4 & 3.91 & 11.49 & 5.57 & 3.03 \\
\hline
\end{tabular}

$\mathrm{VC} \%$ means variation coefficient.

\section{EGG QUALITY}

The results of egg quality are represented in Tables $\mathrm{V}$ and VI, in which no significant differences ( $p>$ $0.05)$ were found for any of the variables analyzed. These results corroborate with the research by Lopes et al. (2008) who also did not find differences for specific gravity, egg weight, yolk percentage, albumen percentage and percentage of bark, noting that the densities do not interfere in the evaluated variables. However, it is important to note that egg quality analyzes were done with fresh eggs and probably significant differences could be found in evaluations over the time of storage. 
TABLE VI

Density effects over \% of egg yolk ( $\%$ yolk), \% of albumem (\% ALB), shell \% (\% shell) and Yolk indices (YI).

\begin{tabular}{lcccc}
\hline TRAT & $\begin{array}{c}\% \\
\text { yolk }\end{array}$ & $\begin{array}{c}\% \\
\text { ALB }\end{array}$ & $\begin{array}{c}\% \\
\text { Shell }\end{array}$ & YI \\
\hline 1 (7 birds/partition) & 27.75 & 64.11 & 8.12 & 0.47 \\
2 (8 birds/partition) & 28.69 & 63.22 & 8.02 & 0.49 \\
3 (9 birds/partition) & 29.21 & 62.91 & 7.86 & 0.49 \\
4 (10 birds/partition) & 29.29 & 62.58 & 8.04 & 0.46 \\
\hline average & 28.73 & 63.21 & 8.01 & 0.48 \\
VC (\%) & 6.9 & 3.19 & 5.23 & 4.16 \\
\hline
\end{tabular}

$\mathrm{VC}(\%)$ means variation coefficient.

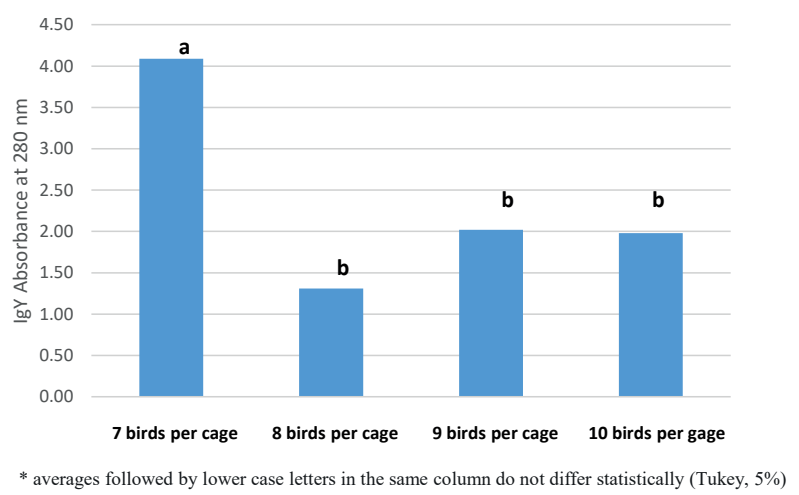

Figure 1 - IgY from Quails eggs at different densities of caging, from 7 birds per cage up to 10 birds per cage.

Nazar et al. (2018) studied the influence of heat stress in the immunoendocrine and biochemical response of quails. During stress period, antibody response was lower, along with other parameters, such as corticosterone, lymphoproliferation, heterophil/lymphocyte ratio (H/L), glucose, total proteins, globulins, and albumen, showing a stress, even for a short time, can influence immune system and its components, reflecting on performance and haching. The results show direct response on egg weight, yolk percentage and albumen.

According to the US Department of Agriculture - USDA (2000), eggs that have an excellent quality have values of Haugh Unit higher than 72, those of intermediate quality, values between 60 and 72 , and those of low quality have values below 60 .
Therefore, although the densities had no effect on quality, the eggs of all treatments can be considered of excellent quality, since they presented values of Haugh Unit around 88.03.

\section{IMMUNE RESPONSE}

The results of the purification and quantification of IgY of quails are shown in Figure 1. Treatment 1 was significantly different from the other treatments, presenting a higher value of IgY immunoglobulins. The values found in treatments 2, 3 and 4 are probably due to the stress generated by the number of birds in the cages.

According to Rosa (2003), in response to stress activation of the hypothalamic-pituitaryadrenal axis occurs, which in turn initiates the release of corticotrophin releasing hormone and adrenocorticotrophic hormone, which result in the secretion of glucocorticoid hormones. Gitoee et al. (2018) measured the IgY from quails eggs in order to stablish a correlation between feed supplementation ad immune system and results showed that the highest IgY level in serum of breeder and their offspring and that of yolk suck and egg yolk were observed in birds fed with Ontop diet, supplemented with organic chromium. Such results show the immune system, through the IgY amount, can respond to any type of interference man can introduce into the production system.

This increase in glucocorticoids can cause various changes in the immune system, which, according to Gray (1988), may inhibit resistance to infections. since large doses of cortisol cause significant atrophy of lymphoid tissue, leading to a decrease in $\mathrm{T}$ cell production and of antibodies (Rosa 2003, Gitoee et al. 2018). In this experiment the results of quantification of type $Y$ immunoglobulins suggest that birds housed at a lower density ( 7 birds) have a higher immunological status than birds that are at higher densities. 
According to Dawkins (2003), animal health is universally accepted as a measure of animal welfare, which makes this assessment of $\operatorname{IgY}$ immunoglobulins another tool available to evaluate the welfare of birds. Gitoee et al. (2018) used the IgY parameter to stablish a correlation between feed supplementation ad immune system and results showed the IgY amount, can responds increasing or decreasing its concentration, depending on the stress managing system birds are submitted.

\section{CONCLUSIONS}

It can be concluded that the densities do not interfere in the quality of the egg, but it impairs the productive performance. The birds of the lower density treatment presented higher values of IgY, promoting better immunological status and wellbeing of the quails.

\section{ACKNOWLEDGMENTS}

We would like to thank Granja Kakimoto for financial support of this experiment and to VICAMI for the donation of the quails. This study was financed in part by the Coordenação de Aperfeiçoamento de Pessoal de Nível Superior Brazil (CAPES) - Finance Code 001.

\section{REFERENCES}

ALBINO LFT AND BARRETO STL. 2012. Codornas: criação de codornas para produção de ovos e carne. Viçosa. MG: Aprenda Fácil, 289 p.

APANIUS V. 1998 Ontogeny of immune function: Avian growth and development: evolution within the altricialprecocial spectrum. In: Starck JM and Ricklefs (Eds), Oxford University Press, New York, New York, p. 203222.

BATKOWSKA J, AL-SHAMMARI KIA, LUKASZ W, NOWAKOWICZ-DEBEK B AND GRYZINSKA M. 2018. Evaluation of propolis extract as a disinfectant of Japanese quail (Coturnix coturnix japonica) hatching eggs. Poult Sci 97(7): 2372-2377.

CAREY JB, KUO FL AND ANDERSON KE. 1995. Effects of cage population on the productive performance of layers. Poult Sci 74: 633-637.
DAWKINS MS. 2003. Behavior as a tool in the assessment of animal welfare. Zoology 106: 383-387.

FAITARONE ABG, PAVAN AC, MORI C, BATISTA LS, OLIVEIRA RP, GARCIA EA, PIZZOLANTE CC, MENDES AA AND SHERER MR. 2005. Economic traits and performance of Italian quails reared at different cage stocking densities. Brazilian Journal of Poult Sci 7: 19-22.

GARCIA ERM, BATISTA NR, NUNES KC, CRUZ FK, BARBOSA FILHO JA, ARGUELO NN AND DE ÁVILA LR. 2015. Desempenho produtivo e qualidade de ovos de poedeiras comerciais semipesadas criadas em diferentes densidades populacionais. Agrop Téc 36: 24-29.

GHAYAS A, HUSSAIN J, MAHMUD A, JAVED K, REHMAN A, AHMAD S, MEHMOOD S, USMAN M AND ISHAQ HM. 2017. Productive performance, egg quality, and hatching traits of Japanese quail reared under different levels of glycerin. Poult Sci 96(7): 2226-2232.

GITOEEA, SADEGHI GAND KARIMIA. 2018. Combination Effects of Organic and Inorganic Chromium on Production Performance, Reproductive Response, Immune Status, and Maternal Antibody Transmission in Breeder Quails Under Heat Stress. Biol Trace Elem Res 184(2): 508-516.

GRAY JA. 1988. The psychology of fear and stress, $2^{\text {nd }}$ ed., New York: Cambridge University Press, 422 p.

JALAL MA, SCHEIDELER SE AND MARX D. 2006. Effect of bird cage space and dietary metabolizable energy level on production parameters in laying hens. Poult Sci 85: 306-311.

KLEMPERER F. 1983. Uber naturliche immunitat und ihre verwerthung fur die immunisierungstherapie. Arch Exp Path Pharmak 31: 356-382.

LEANDRO NSM, VIEIRA NS, MATOS MS, CAFÉ MB, STRINGHINI JH AND SANTOS DA. 2005. Desempenho produtivo de codornas japonesas (Coturnix coturnix japonica) submetidas a diferentes densidades e tipos de debicagem. Acta Scietiarum Animal Science 27: 129-135.

LIMA HJD, BARRETO SLT, VALERIANO MH, VIEIRA DVG AND COSTA SL. 2012. Densidade Inicial de Alojamento de codornas japonesas na fase de postura. Global Sci Technol 5: 186-193.

LOPES IRV, FUENTES MDFF, FREITAS ER, SOARES MB AND RIBEIRO PS. 2008. Efeito da densidade de alojamento e do nível de energia metabolizável da ração sobre o desempenho zootécnico e características dos ovos de codornas japonesas. Rev Ciência Agronômica 37: 369375.

MOLENTO CFM. 2005. Bem-estar e produção animal aspectos econômicos - Revisão. Arch Vet Sci 10: 1-11.

NAZAR FN, VIDELA EA, FERNANDEZ ME, LABAQUE MC AND MARIN RH. 2018. Insights into thermal stress in Japanese quail (Coturnix coturnix): dynamics of immunoendocrine and biochemical responses during and after chronic exposure. Stress 21(3): 257-266. 
PASTORE SM, OLIVEIRA WP AND MUNIZ JCL. 2012. Panorama da coturnicultura no Brasil. Revista Eeletrônica Nutritime 9: 2041-2049. Disponível em: <http://www. nutritime.com.br/arquivos_internos/artigos/180\%20 Panorama\%20da\%20coturnicultura_.pdf $>$. Acesso em 12 de dezembro de 2015.

PAVAN AC, GARCIA EA, MÓRI C, PIZZOLANTE CC AND PICCININ A. 2005. Efeito da densidade na gaiola sobre o desempenho de poedeiras comerciais nas fases de cria, de recria e de produção. Rev Bras Zootec 34: 13201328.

R CORE TEAM. 2015. A language and environment for statistical computing. R Foundation for Statistical Computing. Vienna. Austria. Available at: $<$ https:// www.R-project.org/>. Access on 23 may, 2018.

ROSA JP. 2003. Endocrinologia do estresse e importância no bem-estar animal. Seminário disciplina Bioquímica do Tecido Animal. Disponível em: < http://www.ufrgs. br/lacvet/restrito/pdf/stress.pdf>. Acesso em 18 agosto de 2016.

ROSTAGNO HS, ALBINO LFT AND DONZELE JL. 2011. Tabelas brasileiras para aves e suínos (Composição de alimentos e exigências nutricionais). $3^{\text {a }}$ ed., Viçosa. MG: UFV, 252 p.

SAKA JO, OYEGBAMI A, OKERE IA, OMOLE AJ AND FAYENUWO JO. 2018. Production systems of Japanese quail (Coturnix coturnix japonica) in the urban communities of southwestern Nigeria. Trop Anim Health Prod 50(6): 1295-1303.

SQUIRES JE. 2003. Applied Animal Endocrinology. Cambridger: GABI publishing, $250 \mathrm{p}$.

SUN H, CHEN S, CAI X, XU GAND QU L. 2013. Correlation analysis of the total IgY level in hen serum. egg yolk and offspring serum. J Anim Sci Biotechnol 4: 10.

USDA - US DEPARTMENT OF AGRICULTURE. 2000. Egggrading manual. Washington: USDA, $75 \mathrm{p}$. 